\section{CAUSES OF ERROR IN THE DIAGNOSIS OF DISEASES OF THE JOINTS *}

\section{WISNER R. TOWNSEND, A.M., M.l. NEW YORK}

Surprise is often expressed by those who specialize in medicine at the number of erroneous diagnoses in the patients who are referred to them for treatment. 'The expert eertainly should be able to malse more correct diagnoses in the line of work that he is an expert in than one who is not specializing; but even among so-called experts error's are frequent and the correct diagnosis is sonsetimes never made, and in other instances many men are seen before the true nature of the disense is arrived at. Much could be written on the neessity for a correct diagnosis as preliminary to correet treatment, and in many instances errors in diagnosis involve serions results for the patient, as faulty treatment may actually render conditions worse; but this phase of the subject does not need to be elaborated. In this connection, however, I quote the following from Richard C. Cabot:1

I. wish in this paper to make three points: 1. A goodly number of "classic," time-honored mistakes in diagnosis are familiar to all experienced physicims locause we make them aguin and aguin. Some of these we can avoid; others are almost inevitable, but all should be borne in mind and marlied on medical maps.by a danger-signal of some kind: "In this vieinity look out for hidden rocks," or "Dingerous: turn here, run slow." I shall enumerate some of these danger points presently.

2. Some common discases are relatively inacessible to dingnosis, no matter how eurefully we are on the wateh for them. From the study of 3,000 antopsies, I have begun to work out a percentage or ratio of acessibility for the commoner diseases.

3. Besides the classic and well-known pitfalls there are some less familiar to the profession and needing all the more, therefore, to be marked "dangerous."

Most physicians believe that Pott's diseasc of the spine is easily recognizel because of the "knuckle" in the spine, the pressure signs, muscular rigidity and secondary abscesses, but the difliculty is precisely in that group of enses which do not show these signs.

Some of the most humiliating yet almost unavoidable failures of my experience have been made in cases which showed post mortem the lesions of Pott's disense. Only four of the seventeen cases that came to autopsy in this series of 3,000 post mortems were recognized in life. In ten of the thirteen "misses" there is "no blame to be nttached to the oflicial in elarge." 'The diagnosis was not suggested by any of the facts at our disposal. The clinieal pieture was usually that of all overwhelming infection (miliary) which was called "septicemia from palvic abscess" (really a psoas abseess), "meningitis," "acute uremia" (two), "septic serotum," "otitis media with pyemia," "pneumonia" (two) and "septic hand with general sepsis."

In two cases there: was a slight kyphos which should have been noticed, but as it lind been there for many years without cliange, it was ignored. In one case there was a gradual, even curve of the whole spine diagnosed by a skilful orthopedic consultant as spondylitis deformans.

The ages of the thirteen patients whose disease was unrecognized were: $20,51,54,81,29,44,49,53,50,64,65,45,40$. The average is fifty year's. In the four recognized cases the ages were $34,40,34,21$ (average, 32 ).

The moral is that we do not look or ask carefully enough for evidence of old vertebral tuberculosis in elderly patients, because we associnte the disease with youth.

* Read In the Section on Orthopedic Surgery of the Amcrican Medical Association, nt the Sixty-Fourth Annual Session, beld at Minncapolis, June, 1013.

1. Cabot, IRlchard C. : Dlagnostle Pitfalls Identlied During a Study of 'Jhree 'Thousand Autopsles, The Jounnal A. M. A., Dee. 28,2912, p. 2205 .
T'o those who specialize in orthopelic surgery it seems rather strange that so many errors should be made in the diagnosis of adult Pott's disease, but it only shows low necessary is a complete, careful examination of the entire body in cases in which the symptoms are not absolutely clear, because a complete examination of this lind would often reveal the true conditions present.

The perentinge of eorrect diagnoses in Cabot's series varied greatly. The smallest was 16 per cent, in acute nephritis as compared with 92 per cent. in diabetes mellitus. Just what the perentage of error is in the diagnoses of disenses of the joints, it is difficult to state, but it has secmed desirable to bring together a few facts which might help those who have to make such diagnoses, to guard against errors that are avoidable. It is for that purpose that this article has been written, and in it no attempt will be made to print a list of all the diagnoses that could be made for any given condition or all the posible errors that are encountered in the diagnosis of any given condition.

The chice causes of error are:

1. Failure to obtain a proper history.

2. Failure to make a proper examination.

3. Failure to take a roentgenogram.

4. Failure to interpret the Roentren findings properly.

5. Failure to use laboratory methods as aids to diagrnosis.

6. Failure to adjust laboratory findings and clinical symptoms properly.

r. Failure by many physicians to realize their limitations-crroneous diagnoses due to ignorance.

'The failure to secure a proper history is responsible for many errors of diagnosis, and the traumatic theory of the causution of joint-diseases was largely due to the failure to secure good histories, to ascertain the true facts or all the facts in the history of the patient with jointdisease. Many of these conditions oceur in early childlood and in many instances the parents will attribute the symptoms to a fall, insisting that the child was perfectly well until then. A careful cross-examination, however, will show that night cries, intermittent pain and lameness may have existed for months but were not considered of any importance until the symptoms became aggravated as the result of some more or less serious traumatism.

$\Lambda$ large number of the cases of Pott's disease in $m y$ experience have been attributed to the negligence of a nurse in allowing the child to fall, and the smallest of knuckles of the spine occurring in children of 4 or 5 may be ascribed to some traumatism of early life, or even pass unnoticed for a long time, or a careful history will show that the present symptoms had no connection with the traumatism which is held responsible for them. Systematic and careful histories should be taken in all cases of joint-disease and the teachers in the medical schools can do no greater service to their students than to impress on them the necessity for careful history taking.

It is essential if one is to draw any definite conclusions as to the causation of any given diseased condition, and a careful and well-taken history will clear up many obscure and involved condilions. Joint-diseases oceur with, or are cansed by, many infections processes, and a good history will tell one whether the patient has or has had typhoid fever, scarlet fever, pneumonia, gonorrher, syphilis, a new lesion, or an inherited one, a sore throat, and whether or not antitoxin was used, a tabes dorsalis, or any of the various forms of nervous disense accompanied by or followed by joint lesions. 
I have seen errors made in joint lesions of all of the before-named conditions in which a good history would have made conditions clear. For hospital or even private work history sheets or cards are jnvaluable and hasten history taking and assist in securing all of the desired facts relating to any given disease.

The history will also be of great help. If taken in connection with printed cards in causing the observer to think logically and not to lay too much jimportunce on the trivial facts which are to the patient often the most significant, and thus made the most prominent in his details of the symptoms for which he applies for diagnosis or treatment.

At present the subject of heredity is not considered of so much importance as formerly, but it is of some value and that subject and the method of life and the sulroundings in which the patient lives or has lived can be ascertained only by a careful history. JTereditary syphilis is very important, and knowlerlge can be secured in many instances only by careful and diplomatic crossquestioning. 'The listory of mother and father should be taken separately, without knowledge of the other. Not only may the information be of value in arriving at a diagnosis, but it may also be of use in treating the parents and avoiding further inlerited conditions.

As one sees patients in consultation one is also impressed with the fact that the physician who has a careful history, preferably a written one, to present is far less frequently liable to make an error in diagnosis than the one who has no clear idea of the history of the patient's previous condition. The failure to secure a good history is usually due to laziness or too great haste in the examination, although some physicians, like some lawyers, seem to lack the power to cross-examine properly. As most of those who contribute to medical literature draw most of their material from hospital wards rather than from private practice, they probably appreciate more fully the value of a good history than do those whose practice is exclusively among private patients; but the latter class of physicians conld contribute fully as valuable material to medical literature if by a slight additional eflort they would take histories of the most important of their cases, if not of all.

Most physicians can recall errors made in diagnosis from a failure to secure a good listory of the caee, and I feel that with the great tendeney toward submitting everything that can be submitted to a laboratory test, the value of taking a proper history of every patient should be insisted on more strongly to-day than ever.

The failure to make a proper examination is also a frequent cause of er'rors of diagnosis. In childhood there is no excuse for lack of a thorough examination because children, even those in the second decade of life, are usually not close observers, and it is essential that they be examined with the clothing removed, and no objection is made to this procedure in either sex. In adults it is different. It takes time to dress and undress, and the physician is often hurried and yields to the wishes of the patient that only a partial exanination be made. Many women also oljeet to undressing for an exannination, and sometimes much tact is required to secure their consent. 'The large number of error's in the diagnosis of Pott's disease referred to by Cabot were largely due to failure to make a proper examination, and his statement that "The moral is that we do not look or ask carefully enough for evidence of old vertebral tuberculosis in elderly patients" is interesting; but not all of these cases in adults are by any means old vertebral tuberculosis. Many are recent infections. To eximine the spine of every patient applying for treatment would be absurd; but if it could be done in many instances it might be of value to both patients and doctor.

'I'hat Pott's disease in the allult is frequently overlooked, apart from Cabot's statisties, is a well-known fact. 'Two patients that I have referred to in another' paper, in which the stomachs were washed out for varying periods by capable physicians, illustrate the failure to recognize a Pott's disease. The diagnosis of the same disease and of a lateral curvature by the dressmakcr is not infrequent, because of failure of the plyysician to make a proper examination. The diagnosis of osteitis of the hip, knee or other joint and the overlooking of an active Pott's disease is not infrequent. The sume is true of any active or acute discase. All attention is centered on it and other lesions overlooked, because they are not looked for. linlarged and suppurating tonsils, carious teeth, pyorrhea, ostcomyelitis of alveolar processes and jaws, swollen or bleeding gums, are all important in seeking obscure causes of infection.

I must acknowledge that to careless or hurried examination 1 have to credit most of my crrors in diagnosis, and from conversation with colleagues I believe that it is the most frequent of all causes and that it is avoidable. To call attention again to this fact is therefore proper. Among the many new methods of cliagnosis or aids in diagnosis is roentgenoscopy. It is of great aid in some instances and a great disappointment in others. A good roentgenogram may show something, while a poor one will show nothing. In early, incipient eases in which its aid is most helpful, even the best of roentgenograms often slow nothing; but in case of doubt one should always be taken, if possible. It may show something and it will help in case of future trouble. It will show that everything possible was done to make an accurate diagnosis. In malpractice cases many arguments have been advanced by the attorneys to show that as there was a doubt as to diagnosis a roentgenogram should have been taken to clear up the doubt, and the failure to talie one was "negligence." This is an extreme view; but as roentgenoscopy is so commonly employed, this aid to diagnosis should be more freely used.

Too much reliance must not bo placed on the interpretation in roentgenoscopy. Experts differ wonderfully and no reliance should be placed on a poor roentgenogram in which one tries to see what he desires to see and no one elfe can see. Such a series of plates was sent me a few day's ago with a diagnosis of osteo-arthritis of the spine. 'That was the dingnosis made by the physician in charge. As the consultant, I had asked for some roentgenograms, and they were male. The roentgenologist confirmed the diagnosis. The plates were shown by me to a number of men, and the only possible diagnosis that could be made from them was that they were attempts to take roentgenograms of the spinal column. Not even magnifying glasses and electric lights in boxes revealed any details to suggest the diagnosis made by the roentgenologist. 'Tlis is not infrequent and may cause serious errors in diagnosis.

Another error is to misinterpret the finclings in either a good or poor roentgenogram. Foci of disense are found where none exjst and are overlooked when they are present. I have seen both conditions in which more careful examinations confirmed the fincts. In one instance a focus of disease was slown on a print and no one could find it on the uriginal plate; ret it 1 eally existed. The prints are usially not so satisfactory as the original plates. 
Most plates make poor prints, and it is often impossible to see anything on a print. $\Lambda$ blurring of a joint-surface may be taken for a beginning disease when it really is due to the fact that the patient moved during the taking of the picture. Occasionally a view in one plane will reveal facts that a view in another plane does not show. In developing the plate valuable data may be hidkden or elearly brought out, and errors of photographie development may be responsible for false ideas as to what the roentgenogram really shows.

Negative findings should not be considered except very rarely. No one should ever make the mistake of ignoring clinical symptoms. Every question of doubt must be decided in favor of the existence of disease when the Roentgen findings are negative.

Firrors due to placing reliance on roentoenoscopy are numerous and are encouraged by the statements of many Roentgen operators, that if disease is present the roentgenogram will surely show it. 'lhis is not founded on careful observation or: thorough knowledge. Many early conditions camnot be detected by the Roentgen ray. In very fat per'sons clear pictures al'e the exception, and in early ehildhood soft bones and epiphyses do not lend themsclves readily to elear and distinct differences hetween the normal and abnormal. 'Therefore, the caution is needed, do not rely too much on the roentgenogram; ignore it entirely if it is a poor one, or if no skilled expert has the opportmity to interpret it. What the average physician does not know about roentgenograms would fill many a volume, and even some experts have much to lcarn.

The laboratory aids to diagnosis are so important that they are boing used more and more. Tn some instances they, too. fail to give us information in the early cases of joint-disease, so that one must, as in lioentgen-riny findings, be careful not to place too much reliance on a negative finding. The positive findings are of the greatest possible value. A positive Wasscrmann or a complement-fixation reaction in syphilis, a demonstration of gonococei, or the complement-fixation reaction, a positive tuberculin test or the presence of bacilli of Kods in sputum or in any of the discharges, and the presence of pneumococei and other bacteria make diagnoses possible of a definite kind that clinical symptoms con only suggest. 'The latter indicate disease of a joint, the former' the nature of the infection. A leukocytosis may also be of value in differentinting different disensed condition. The laboratory findings must be interpreted intelligently. Not too much reliance must be placed on a tubcreulin or Wassermann test in which the clinical symptoms "do not fit," so to speak. Such a case is the following:

A positive tubereulin test was obtained in an alult with a low leukocy te count, a swollen ankle, a tender sjot and swelling of lower third of tilia, a septic temporature aseribed to tuberculosis by the bneteriologist diagnostician, and loss of weight aseribed to tubereulosis by the family physician. There was a cough, but examination of sputum was negative. Roentgenoscopy at first was negative, and a diagnosis of osteomyelitis was made. 'Two weoks later Roentgen findings were positive, revealing a focus at the site of temlerness in the tibia. Operation was consented to. On the day before the operation there was a high leukocyte count; pus was found and evacunted; the temperature becume normal; the cough disuppeared; weight was more tlun regained, and the dingnosis of tubereulosis proved incorrect.

The general rule is that a high leukocyte count does not occur in bone tubereulosis but only in cases of infection by pyogenic organisms. 'The high eount just before the operation confirmed the diagnosis. Other experiences of this kind occur to all and render caution necessary. The existence of two disensed conditions present in one person at the same time must be considered.

The prevalence of certain forms of arthritis varies greatly according to surroundings and conditions. Take for instance the table of Bactz, ${ }^{2}$ who found in 100 cases of acute arthritis anong negro liborers on the Camal Zone 63 cases of syphilitic arthritis, 28 of gonorrheal arthritis, 6 of undetcrmined arthritis, 2 of dysenteric arthritis and 1 of tuberenlous arthritis. This is rather starting but easily accounted for by the conditions: a large male population made up of single men of low morals, with venerenl disenses prevalent. No private practice in the United States would show the same proportion of causes of infection. All tests of laboratory type must be carefully interpreted, and the views of Craigs of the Army Medical Corps, express clearly the various interpretations that are to be given to the test, and elose with these very pertinent remalks, which should be always followed by all who have to treat discase:

lior this reason the test should be made only in properly equipped laboratories by those who have received special instruction and who devote a large part of their time to this work. Under such conditious results will be satisfactory, but the interpretation of the test must nlways remain with the clinician. The laboratory report deals only with the result of the test, and it rests with the elinician to correlate this result with the elinical condition present.

Eirors due to failure of plysicians to recognize their limitations may in some instances be prevented by the sald experiences that sometimes follow serious errors. Many physicians are most conscientious in this respect, either declining to trent a given case or at once calling in an expert. A few others, some posing as specinlists in some line in which joint cases are seldom seen, take such patients and continue to make the diagnosis of rheumatism for every joint lesion seen. For accurate diagnosis it would be well if the term "rheumatism" could be omitted entirely from nomenclature. Kenneth Goadby ${ }^{4}$ says :

The term "rheumatism," like muny another medical word, has come to designate a multitude of disenses, and covers many sins of commission and omission in diagnosis. Omnibus words of this type are, no doubt, very useful, but tend to lamper exact description.

This class and the ignorant physicians who do not know a diseased joint when they sec one are hopeless. No article ever written will reach them. Fortumately they are few in number and their number is becoming less each year.

125 West Fifty-Jiglith Street.

\section{ABSTRACT OF DISCLISSTON}

Dr. D. J. Cinfritr, Kunsas City, Mo.: There are some other joints in which we are sometimes linble to make errors in diagnosis without the use of all the aljuncts of which Dr. Townsend has spoken. At any rate, the Roentgen ray is sometimes not available for use, and the patient eomes with a ding. nosis of other troubles besides the spimal one. This experience occurred to me in the ease of a child, aged 10 years, who was brought to me with a history of knee-joint trouble it seems that, four or five years before, she land jumped and landed on one foot, instend of on both feet. Suddenly she

2. Buctz, Walter: One IIundred Calses of Acute Aithritls Amono Negro laborers on the Janama Cama, 'Tud JourNa. A. M. A., Aprif 5,1913, b. 1005

3. Crig, $C$. F.: Interpretation of the results of the Wasser-

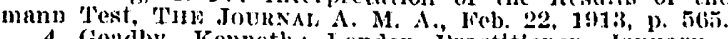

4. Gondby, Kenneth: london iratitioner. Jinuav. 1912. 
experienced pain in the knee and just below it. She was brought to me after laving had treatment for knee-joint trouble, of which she had had occasional attacks. At the tubercle of the tibia, but nowhere else, there was pain on pressure; she had passed over the point of temporary synovitis produced when she struined the joint. We found, on minking a roentgenogram, one of those unusual cases that $\mathrm{Dr}$. Osgood presented several years ago before the American orthopedic Association. The tuberele of the tibin was torn off by the quadriceps tendon through some overexertion. The epiphysis had not been joined onto the diaphysis and had torn loose-Osgood-Sehlatter disease.

Dr. Henry JjNG TaYlon, New York: There is one diagrnosis that Dr. Townsend did not speak of that every orthopedic surgeon should be able to make, and that is the diagnosis of whether a roentgenogram is good or bad. The importanne of this fact came out in practice when a medicolegal case was brought for diagnosis. The patient, a woman, was lame and had tenderness back of the hip, but the symptoms did not resemble any kind of arthritis of the hip. Her physician bronght a series of roentgenograms to me and said: "Do you not see a cyst in these plates?" "No," I replied. "What do you see?" he asked. I said, "I see a poor roentgenogram." It was very cloudy. I insisted on having a series of good roentgenograms before I made a positive cliagnosis. They showed no cyst but a button of bone divulsed, pulled out, just behind the obturator fossa. It was a unique case. I never saw or heard of one like it. This button of bone showed plainly in a series of five or six roentgenograms, taken in five or six different positions; this eleared up the diagnosis absolutely.

Dis. E. W. Caldweld, New York: I am glad to have an opportunity to express my approval of all that Dr. Townsend said about the danger of misinterpreting roentgenograms, and especially about the usual inaccuracy of hospital roentgeno. grams. For many reasons, which I shall not discuss at present, it is difficult to get good roentgenographic work in any hospital or similar institution. Sometimes it is a question of money. Often, however, it is a question of recognizing that Roentgen diagnosis is not photography. Many hospitals want to have this work done by a photographer. Although some photographer's can be taught to make good-looking platess, we have all lad plenty of oceasion to know that the photographer's plate jis not safe.

Dr. Reginald 13. Saym, Now York: I often find that I do not get the true history of these cases until many months after 1 have been treating the patient, not on account of intentional falsification on the part of the patient, or on account of carelessness on my own part; but now and then, something will be said that will bring to light a fact that has been lost sight of absolutely.

There are one or two pitfalls in diagnosis that $I$. have lappened to notice, which I do not think J). Townsend mentioned. One is the possible error in mistaking anterior poliomyelitis, in the first few days of its course, for joint aflections. I have seen three cases of this disense that were brought to me on account of a painful limp, and had almost all the earmarks of $n$ beginning tuberculosis of the hip or of a begimning hip-joint inflummation. Being uncertain as to the diagnosis, J asked the child, in each instance, to come back again at the end of a week for further nuvestigation; and at the second appearance the child showed distinct evidences of the existence of anterior poliomyelitis and subseguently went through the course of that disease. This is a fact worth bearing in mind.

I have also seen several liysterical knees (so-called), which depended on a reflex uterine lesion and disappenred after the uterus had been put in place and retained there. I have likewise seen a casse of supposed tuberculosis of the spine that had been treated by a number of men, which was also due to a retroflexion of the uterus. There was spinal distortion, weakness in the leg and atrophy of the muscles on the aflected side, all of which disappeared after replacement of trie uterus. I believe that cases of this kind are more fre- quently met than we are generally led to suppose; and I can certainly agree with Dr. Cabot concerning the freguency with which Pott's disease in the adult is overlooked, as I have seen a large number of patients with this disease who had been in various hospitals and had been trented for various things. I remember one patient who had been originally referred to the hospital by the attending physician for Pott's disease; but there, slee was not operated on for Pott's disease, but for a lacerated cervix. The patient was then sent back to the attending physician, but her symptoms continuing, she returned to the hospital later for another examination. On this occasion the hospital physician turned the patient over on her face, and found a knuckle in the spine, which had probably been there all the time. Fulure to look for such things is probably the reason for not observing them more frequently.

\section{THE PASSING OF THE FAMILY DOCTOR *}

\section{GEORGE W. GUTIIRIE, M.D.} WILKES-BMARRE, PA.

Lowell says, "Time makes ancient good uncouth." The whole trend of modern thought is to look for a new and better way. We travel, literally, in chariots with horses of fire. Jules Verne's dream of "Around the World in Eighty Days" has been more than realized and the stories of the Arabian Niglits are equaled by the every-day events of common life.

Even our sentimental life has changed. The beautiful story of Uncle Toby and the fly that was an inspiration to our boyish imagination and the pieture of the kindly old man opening the window and saying, "There's room enough in this world for both thee and me" has been changed to the slogan "swat the fly." We have come to agree with Cowper in reference to the lower animal's that

\section{If man's convenience, lealth or safety interferes \\ His rights and claims are paramount and must extinguish theirs.}

But in no realm of human activity has the advance of modern thought caused such changes as in the practice of our profession. In the past one physician, the family doctor, was deemed competent to meet all the exigencies of life requiring medical aid; he was physician, surgeon, obstetrician, oculist and pediatrist.

P'resident Wilson, ${ }^{1}$ in his admirable address of welcome as governor of the state of New Jersey, to the American Medical Association in Atlantic City on June 15, 1912, suid:

I believe you will agree with me that one of the things to be regretted in our modern time is that we have been obliged to specialize our professions to so great a degree, because in proportion as the medical profession is specinlized, for example, the old fanily physician disappenrs. I remember going over in my memory a single yeur of my family life with my children when they were small and finding that I had called in consultation thirteen different specialists. There was no ill luck in the thirteen because it all came out very happily. But where I lad summoned thirteen specialists, my fither would have summoned one fumily physician. My father would not lave got as good adviee as $I$ got, and yet I lived through it. But every time he sent for his doctor he was sending for a persomal friend. He was sending for a man who had his confidence in a peculiar degree. He was sending for a man who walked the paths of life with him as a com-

* Presldent's Address, read before the Lehigh Valley Medicul Assochation, July 1\%, 1013.

1. Govecnol" Wilson's Address of Welcome, Tile Juvaral A. M. A, Junc 15, 1012 , p. 1013 